\title{
REVIEWS
}

Adv Clin Exp Med 2015, 24, 1, 153-159

(c) Copyright by Wroclaw Medical University

DOI: $10.17219 /$ acem/28626

ISSN 1899-5276

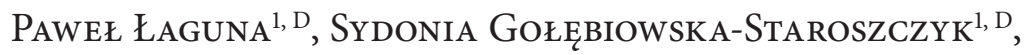
Maciej Trzaska ${ }^{2, D}$, MaŁgorzata GrabarczyK ${ }^{1, D}$, Micha£ Matysiak ${ }^{1, D}$

\section{Immunoglobulins and Their Use in Children}

${ }^{1}$ Department of Pediatrics Hematology and Oncology, Medical University of Warsaw, Poland

${ }^{2}$ Octapharma, Poland

A - research concept and design; $\mathbf{B}$ - collection and/or assembly of data; $\mathbf{C}$ - data analysis and interpretation;

$\mathbf{D}$ - writing the article; $\mathbf{E}$ - critical revision of the article; $\mathbf{F}$ - final approval of article; $\mathbf{G}$ - other

\begin{abstract}
Immunoglobulin preparations are one of the products of the human plasma fractionation, where the plasma is obtained, in accordance with WHO guidelines from at least 1,000 donors. These preparations contain all IgG subclasses with various antigen characteristics. In clinical practice these drugs are used as replacement therapy in patients with primary and secondary immunodeficiencies as well as immunomodulatory therapy in many autoimmune diseases and systemic inflammatory diseases. Here we present characteristics of i.v. polyvalent, human immunoglobulin preparations available on the Polish market and the possibilities of their use in clinical practice, in children with hematological diseases. Considering the very low consumption of immunoglobulin preparations in our country as compared to other European countries, we would like to draw the attention of medical professionals, especially pediatricians and haematologists, to the benefits that stem from the use of these drugs in the therapy of children with haematological diseases. Our work will also facilitate the choice of an optimal polyvalent human immunoglobulin preparation for a particular patient (Adv Clin Exp Med 2015, 24, 1, 153-159).
\end{abstract}

Key words: i.v. immunoglobulin preparations, immune thrombocytopenic purpura, children.

Immunoglobulin preparations are one of the products of human plasma fractionation. These drugs are concentrates of all IgG subclasses. In accordance with WHO guidelines, the plasma used for the production of immunoglobulins should be obtained from at least 1,000 donors. This ensures a variety of antibodies in the final product, providing its clinical universality [1]. In clinical practice, intravenous human immunoglobulin preparations (IVIG) are mostly used as replacement therapy in patients with primary and secondary immunodeficiencies, such as congenital hypo- and agammaglobulinaemia, Common Variable Immunodeficiency (CVID), severe combined immunodeficiency, Wiskott-Aldrich syndrome, recurrent infections in patients with AIDS or severe infections. IVIG are also very useful in haematology, especially paediatric haematology, neurology and rheumatology.

\section{Aim}

As there are so many different iv immunoglobulin preparations on the market, we have decided to present their characteristics and clinical use. We would also like to point out the differences in the manufacturing process which, by influencing physico-chemical end-parameters of particular products, may affect therapeutic efficacy within this, only apparently homogenous, group of drugs.

\section{Manufacturing of iv Immunoglobulin Preparations}

As we have already pointed out, immunoglobulins are one of the products of human plasma fractionation. Industrially there are two similar methods used in human plasma fractionation: 
the Cohn-Oncley fractionation process, the Kastler-Nitschmann method.

During fractionation plasma is submitted to sequential precipitation and split into fractions using variable concentrations of ethyl alcohol, $\mathrm{pH}$, temperature and ion exchangers [2, 3]. Out of each fraction, after discarding impurities, valuable medications are produced: albumins, clotting factors and, of course, immunoglobulins. An exemplary Cohn-Oncley fractionation process is presented on graph 1 [4]:

The Kistler-Nitschmann method is similar. It is quicker (one less incubation in alcohol) but does not lead to IgA elimination. That is why, during further immunoglobulin processing, it is necessary to use chromatography to isolate this fraction. Final, ready-to-use IgG should contain no less than 90\% protein, without considering additional proteins used e.g. to stabilize the final product [5].

\section{Techniques Used to Protect Immunoglobulins from Pathogens}

The process of immunoglobulin manufacturing may sometimes raise doubts regarding the safety of these types of products, especially because of the risk of transmitting potential infectious particles or prion infections [6-8]. Analyzing the data in literature, these reservations seem totally unfounded. Statistical data confirms that immunoglobulins available today are safe. In this class of drugs there have been no reports of the transmission of blood-borne infections for over 30 years.

An unquestionable influence on the development of safety procedures in blood derivatives, including iv immunoglobulins, was the discovery of infections in haemophilia patients who were taking clotting factor at the beginning of the 1980s. Insufficient safety procedures led to HIV infections in many of these patients. An 'HIV epidemic' in the haemophiliac population gave an impulse for the production of recombinant clotting factors and for inventing new procedures ensuring the safety of plasma derivatives [9].

The safety of IVIG is guaranteed by a continuous technological progress [10] - refining methods of inactivation of both encapsulated and non-encapsulated pathogens, elimination of pathological $\mathrm{PrP}^{\mathrm{Sc}}$ prions and new filtration methods [11]. These can also eliminate such 'emerging pathogens' as the West Nile virus, Ebola or avian flu, as well as of non-encapsulated viruses and prions [12-15].

It has to be stressed that all iv immunoglobulin preparations available on the Polish market exceed the requirements regarding pathogen

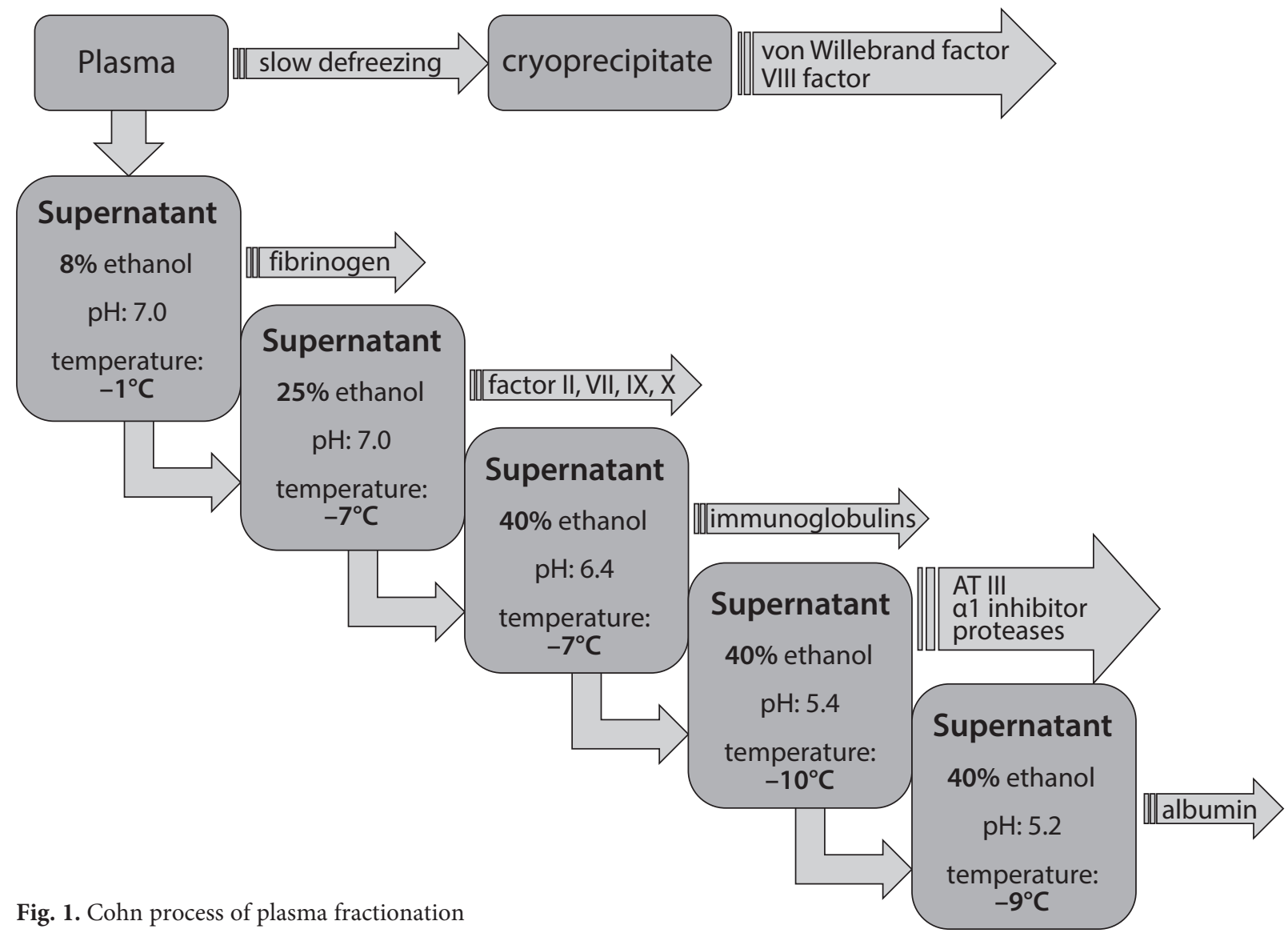


reduction. On average the margin is $>10 \log (10)$ to $>25 \log (10)$ and this best illustrates the safety of these products.

All requirements regarding quality standards that should be fulfilled in the production of immunoglobulins are strictly supervised in a specialized agenda by the European Medicines Agency (EMA) [16, 17]. Plasma used for manufacturing plasma derivatives has to fulfil the requirements of the Plasma Master File (PMF) regarding:

- selection of plasma donors and methods of investigation

- the presentation of scientific data regarding pathogen inactivation procedures used

- the effect of technological changes introduced for the safety of plasma derivatives

- the quality and efficacy of plasma derivatives or drugs containing plasma components

The Plasma Master File has to be regularly renewed [18].

\section{Biochemical Characteristics of Immunoglobulins and Their Potential Effect on Therapy}

As stressed above, although intravenous immunoglobulins seem to be a homogenous group of drugs, the differences in the fractionation, purification and confectioning processes, and above all, in the plasma used for production, significantly affect the proprieties of end-products. That is why different immunoglobulin preparations used to treat the same disease in a particular patient may be differently tolerated and cause different adverse effects.

\section{Pharmaceutical Form and Concentration}

A few years ago, the world markets were dominated by $5 \%$ IVIG solutions or - what was very popular in Poland - 3\% and 6\% lyophilized immunoglobulins. At present the Polish market is dominated by $10 \%$ concentrates of ivIgG (such as Kiovig, Privigen, Octagam, Flebogamma, Intratect). Most of them can be transfused at a higher rate (expressed in $\mathrm{mL} / \mathrm{kg}$ bw per $\mathrm{h}$ ) than $5 \%$ solutions. Shorter infusion time has measurable benefits stemming from the shortening of hospitalization time, which is particularly important in children.

\section{Stabilizers}

Preserving immunoglobulin $G$ in its native form is a challenge for every manufacturer. It is one of the reasons for adding external substances to prevent the drug from aggregation. Most often sugars or amino-acids are used as stabilizers. Sadly, there are no stabilizers that are not potentially linked with adverse effects. One of the most serious complications after immunoglobulin treatment is the risk of kidney failure linked with the presence of sucrose in some of the $\operatorname{IgG}[19,20]$.

Depending on the substance added as a stabilizer, we may expect particular adverse effects enumerated in Table 1.

Table 1. Stabilizers and their most frequent adverse effects

\begin{tabular}{|c|c|}
\hline Stabilizer & Most frequent adverse effects \\
\hline Glycine & $\begin{array}{l}\text { nausea, vomiting, excessive sweating, head- } \\
\text { ache, fever }\end{array}$ \\
\hline Maltose & $\begin{array}{l}\text { blood glucose monitoring systems falsely } \\
\text { recognize maltose as glucose, distorting } \\
\text { glucose readings }\end{array}$ \\
\hline L-proline & $\begin{array}{l}\text { proline-containing IgG are contraindicated } \\
\text { in patients with hyperprolinemia }\end{array}$ \\
\hline Sucrose & kidney damage \\
\hline Sorbitol & $\begin{array}{l}\text { sorbitol-containing IgG should not be } \\
\text { used in diabetics and patients with fructose } \\
\text { intolerance (fructose is one of sorbitol's } \\
\text { metabolites) }\end{array}$ \\
\hline
\end{tabular}

\section{IgA Content and the Risk of an Anaphylactic Reaction}

For years the content of type A immunoglobulin in the i.v. immunoglobulin preparations has been synonymous with potential risk of anaphylactic reactions. That is why all immunoglobulin manufacturers strive for decreasing IgA content in the final product.

Thirty years ago intravenous immunoglobulin preparations with increased IgA content were popular and used to treat viral infections. Studies conducted at that time showed no sign of specific anti-IgA antibodies in the sera of patients undergoing such therapy. No cases of anaphylactic reactions were reported [21]. Anaphylactic reactions after the administration of immunoglobulins rarely resulted in a lack of recommendation for routine screening of patients for the presence of anti-IgA antigens before IVIG administration [22]. It seems 
that the administration of intravenous IgG is safe, even in patients with IgA deficiencies [23].

Another way to reduce the risk of anaphylactic reactions, apart from reducing IgA content, is to modify an immunoglobulin preparation in such a way as to make it suitable for subcutaneous delivery. After administering subcutaneous IgG preparations, inconsiderable resorption into the circulation and a long release time leads to a smaller release of inflammatory mediators [24]. Moreover, this route of administration is safe even in patients with confirmed anti-IgA antibodies $[25,26]$.

Table 2 shows the characteristics of several immunoglobulin preparations presently available in Poland. We have presented only some of the features, those that in our opinion are most important when choosing the best preparation for a particular patient.

\section{Immunoglobulin Mechanism of Action and Clinical Use}

The mechanism of immunoglobulin effect on the immune system is varied and still remains a topic of research. Suggested regulatory mechanisms of immunoglobulin action include:

- stimulating production of some of the cytokines and their antagonists [27-30];

- stimulating B \& T lymphocyte apoptosis by activating Fas receptors [28, 31];

- inhibiting differentiation and maturation of dendritic cells [32];

- increasing catabolism of IgG $[28,29]$;

- modulating expression and function of an Fc fragment through $\mathrm{Fc} \gamma \mathrm{R}$ receptors $[29,30,33]$;

- blocking the binding of T lymphocytes with superantigens [34]

A modulatory factor for immunoglobulins in the immune system is widely used in therapy, especially in the treatment of autoimmune and inflammatory diseases. The following blood disorders are significant: immune thrombocytopenic purpura (ITP), autoimmune haemolytic anemia (AIHA) and pure red cell aplasia (PRCA).

The fact that human immunoglobulin intravenous preparations are safe, have few adverse effects and are usually well tolerated makes them particularly suitable for use in children with autoimmune cytopenias. These preparations have an important role in therapy, especially in the treatment of newborns and babies.

Thus, IVIG are clearly among the best clinically tested drugs in one of the most frequently diagnosed childhood diatheses - the immune thrombocytopenic purpura (ITP) [35-38]. Here the mechanism of action is based mainly on Fc phagocyte receptor saturation and neutralization of anti-platelet antibodies by anti-idiotypic antibodies. Some data suggests that TGF $\beta$ present in the human IVIG solutions affects the auto-aggression process, and that there are anti-cytokine antibodies against interleukin-1 (IL-1) and interleukin-6 (IL-6) (essential for the production of anti-platelet antibodies). The therapeutic efficacy of immunoglobulin preparations in children with ITP is indubitable and the treatment response is similar to that achieved with corticosteroids, with shorter treatment duration [39]. Typical dosing regimen for IgG consist of a dose of $0.4 \mathrm{~g} / \mathrm{kg} / \mathrm{d}$ for 5 days or of a dose of $1 \mathrm{~g} / \mathrm{kg}$ for 2 days [40]. According to some authors, a shorter time of administration and larger doses of IgG result in faster increase in platelet number, even within $24 \mathrm{~h}$.

IVIG are also the drug of choice in fetal and neonatal alloimmune thrombocytopenia. This disease develops when the mother produces antibodies against platelet antigen (most frequently the HPA-1a) inherited by the child from the father. Here IVIG act similarly as in the immune thrombocytopenic purpura (ITP). They should be given to the mother weekly in large doses - on average $1 \mathrm{~g} / \mathrm{kg}$ body weight, and to the child in case his/her platelet count falls below 50,000.

The varied mechanism of action presented above also allows paediatric haematologists to use IVIG in the treatment of an autoimmune haemolytic anaemia or a haemolytic disease of the newborn (HDN).

In patients with parvovirus B19-induced pure red cell aplasia (PRCA), immunoglobulins are used as a source of antibodies against parvovirus B19 and given as a single dose of $0.4 \mathrm{~g} \mathrm{IgG} / \mathrm{kg} \mathrm{ev-}$ ery 28 days [41].

Immunoglobulins are also used to treat acquired haemophilia A. This is a severe diathesis induced by autoantibodies against factor VIII. The disease strikes mainly later in life; however, single cases have been reported in children as well. In about $50 \%$ of patients the disease is considered idiopathic; in the rest a concomitant disease is discovered at diagnosis, most often - a neoplasm (12.5\%), rheumatoid arthritis (14.6\%), SLE (10.4\%) or other autoimmune disorders (8.3\%). A factor VIII inhibitor may also develop in pregnant and puerperal women (7-13.5\% of patients), especially in the first three months after birth. For the treatment of acquired haemophilia A IVIG is used in standard doses: $0.3-0.4 \mathrm{~g} / \mathrm{kg}$ b.w./d for 5 days or $1-2 \mathrm{~g} / \mathrm{kg}$ b.w./d for 2-5 days [42-45]. 


\begin{tabular}{|c|c|c|c|c|c|c|c|c|c|c|c|c|c|c|c|c|}
\hline 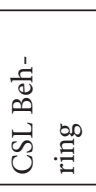 & 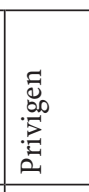 & $\stackrel{\circ}{\circ}$ & 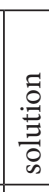 & $\begin{array}{l}\infty \\
\wedge \\
\wedge\end{array}$ & $\begin{array}{l}8 \\
8 \\
0 \\
0 \\
0\end{array}$ & 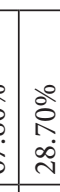 & 离 & 今े & 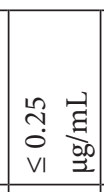 & & 宅 & 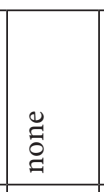 & 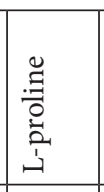 & 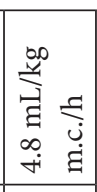 & 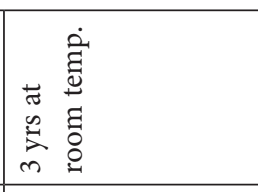 & 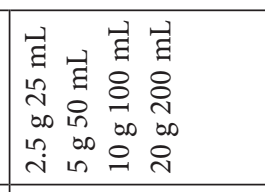 \\
\hline 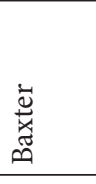 & 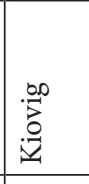 & $\stackrel{\circ}{\circ}$ & 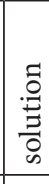 & $\mid \begin{array}{l}\infty \\
\curvearrowright \\
\wedge\end{array}$ & 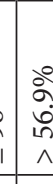 & $\begin{array}{l}8 \\
\dot{b} \\
\dot{0} \\
\wedge\end{array}$ & $\begin{array}{l}\stackrel{\circ}{\leftrightarrow} \\
\dot{\sim} \\
\wedge\end{array}$ & $\stackrel{\stackrel{\circ}{\stackrel{2}{\wedge}}}{\wedge}$ & 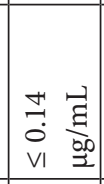 & 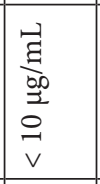 & $\sum_{\sum}^{Z}$ & 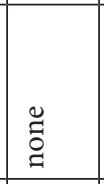 & 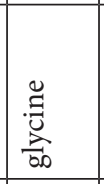 & 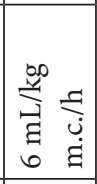 & 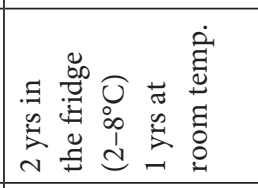 & 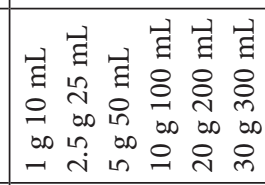 \\
\hline 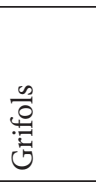 & 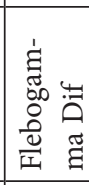 & $\stackrel{\circ}{\circ}$ & 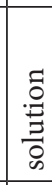 & $\begin{array}{l}\hat{\alpha} \\
\wedge\end{array}$ & $\begin{array}{l}80 \\
8 \\
0 \\
0 \\
0\end{array}$ & 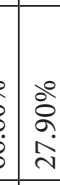 & 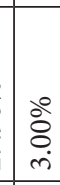 & $\begin{array}{c}0 \\
\text { in } \\
\text { in } \\
i\end{array}$ & 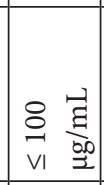 & & & 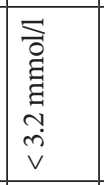 & $\begin{array}{l}0 \\
0 \\
0 \\
0 \\
0 \\
0 \\
0 \\
0 \\
\end{array}$ & 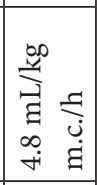 & 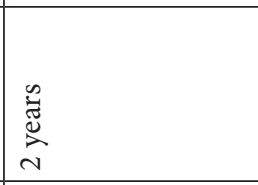 & 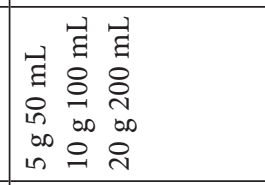 \\
\hline 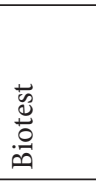 & 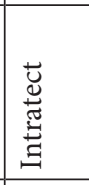 & $\therefore$ & 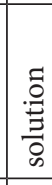 & $\begin{array}{l}\text { ڤ } \\
\text { ㅅ }\end{array}$ & $\begin{array}{l}20 \\
\text { in } \\
\text { in }\end{array}$ & 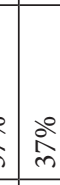 & mे & $\stackrel{\circ}{m}$ & 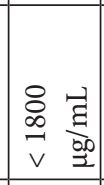 & & & 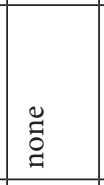 & 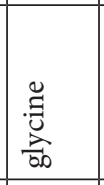 & 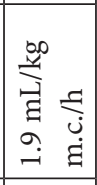 & 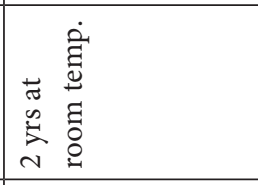 & 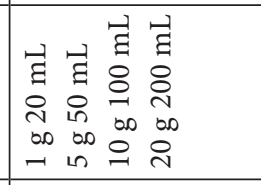 \\
\hline 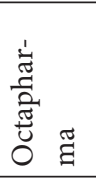 & 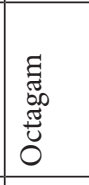 & ठ & 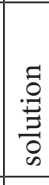 & 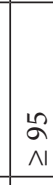 & : & $\begin{array}{l}0 \\
\text { on }\end{array}$ & $\check{2}^{\circ}$ & $\stackrel{\circ}{2}$ & 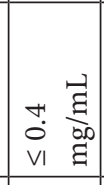 & 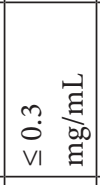 & & 芩 & 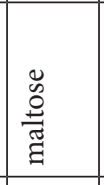 & 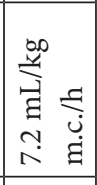 & 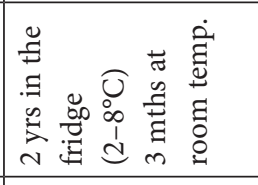 & 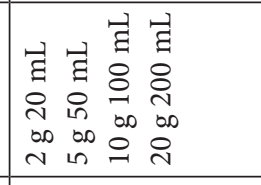 \\
\hline \multirow{3}{*}{ 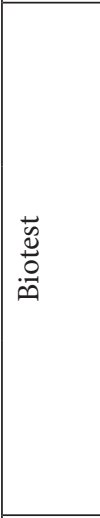 } & 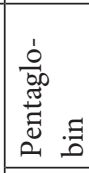 & in & 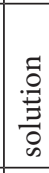 & $\begin{array}{l}2 \\
\Omega \\
\wedge\end{array}$ & 今े & 8 & $\stackrel{\circ}{\%}$ & $\stackrel{2}{1}^{\circ}$ & 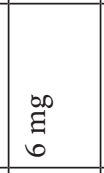 & 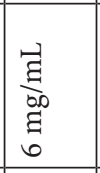 & 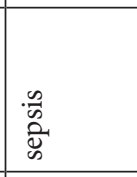 & & 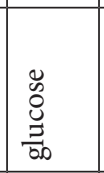 & 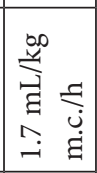 & 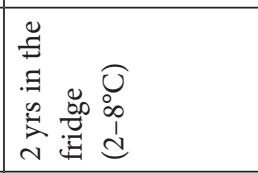 & 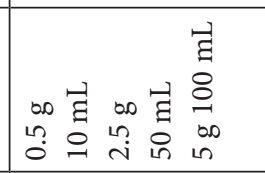 \\
\hline & 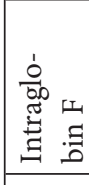 & in & 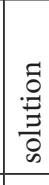 & $\begin{array}{l}\text { L } \\
\text { ॥ }\end{array}$ & స్రి & $\begin{array}{l}\stackrel{\circ}{0} \\
\dot{m}\end{array}$ & $\begin{array}{l}0 \\
0 \\
0 \\
0 \\
0\end{array}$ & 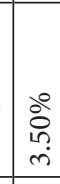 & $\begin{array}{l}\infty \\
\vdots \\
L \\
i \\
i \\
i\end{array}$ & & & 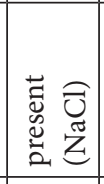 & 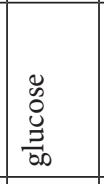 & 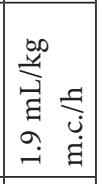 & 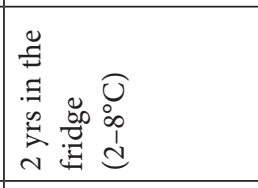 & 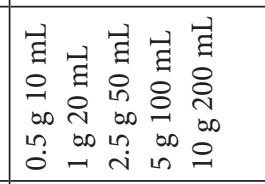 \\
\hline & 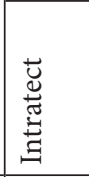 & in & 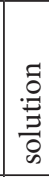 & $\begin{array}{l}\curvearrowright \\
\wedge\end{array}$ & $1 \begin{array}{l}\circ \\
1 \\
\text { in }\end{array}$ & 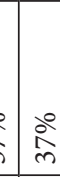 & mे & $\stackrel{\circ}{\circ}$ & 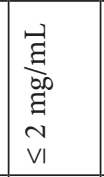 & & & 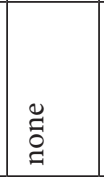 & 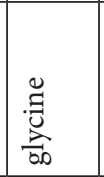 & 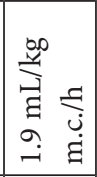 & 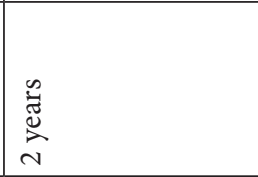 & 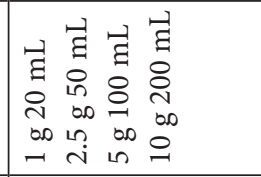 \\
\hline 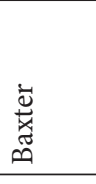 & 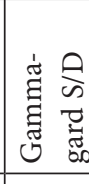 & in & 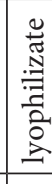 & $\begin{array}{l}8 \\
21 \\
11\end{array}$ & $\begin{array}{l}8 \\
2 \\
b \\
1 \\
1 \\
1 \\
1\end{array}$ & $\hat{\imath}$ & $\begin{array}{c}\stackrel{0}{\circ} \\
\dot{m} \\
\wedge\end{array}$ & $\begin{array}{c}\stackrel{0}{0} \\
\text { हें } \\
\wedge\end{array}$ & 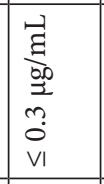 & & & 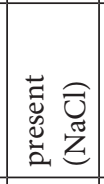 & 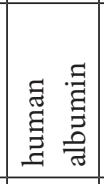 & 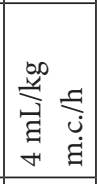 & 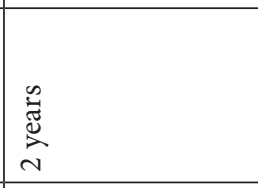 & 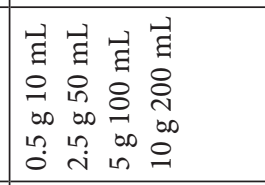 \\
\hline 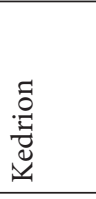 & 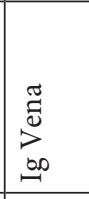 & in & 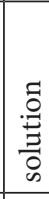 & $\begin{array}{l}\text { ֵ } \\
\wedge\end{array}$ & $\begin{array}{l}80 \\
0 \\
0 \\
0\end{array}$ & $\begin{array}{l}0 \\
\infty \\
\infty \\
\dot{m} \\
\dot{m}\end{array}$ & 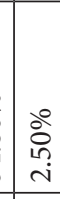 & 客 & 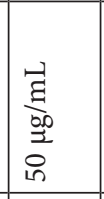 & & 己े & \begin{tabular}{|l} 
\\
$\vec{े}$ \\
$\vdots$ \\
$\vdots$ \\
$m$ \\
$m$
\end{tabular} & 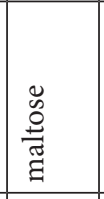 & 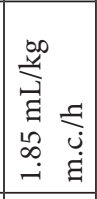 & 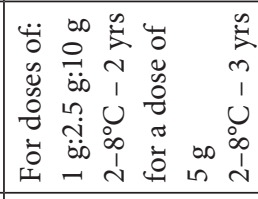 & 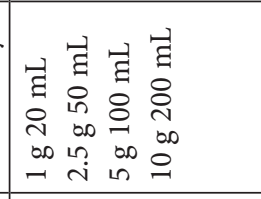 \\
\hline 总 & 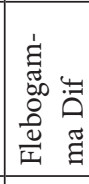 & กั & 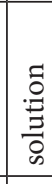 & & $\begin{array}{l}8 \\
8 \\
6 \\
0 \\
0\end{array}$ & 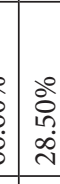 & $\begin{array}{l}\stackrel{\circ}{\stackrel{2}{i}} \\
\text { in }\end{array}$ & ì & 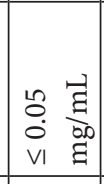 & & & 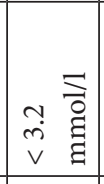 & 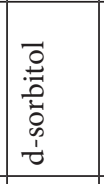 & 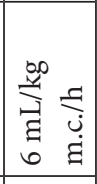 & 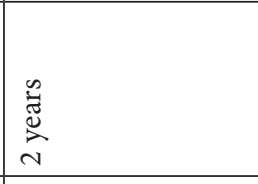 & 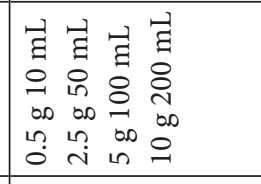 \\
\hline 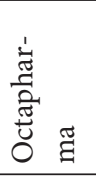 & 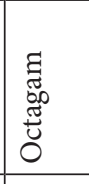 & in & 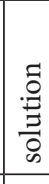 & $\begin{array}{l}\text { L } \\
\text { ㅊ }\end{array}$ & ठें & ळे & $\stackrel{\circ}{\wedge}$ & $\stackrel{\circ}{\beth}$ & 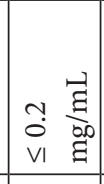 & & & 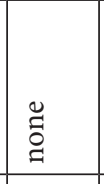 & 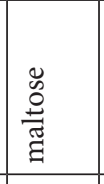 & 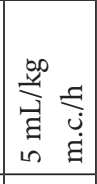 & 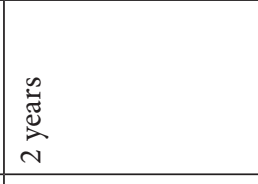 & 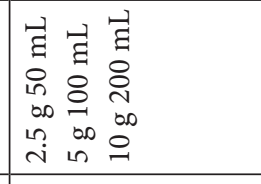 \\
\hline 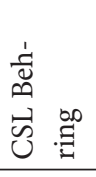 & 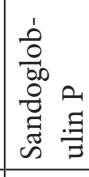 & 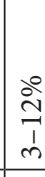 & 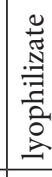 & 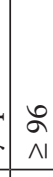 & $\begin{array}{l}\stackrel{0}{\circ} \\
\stackrel{2}{.} \\
\text { in } \\
\end{array}$ & 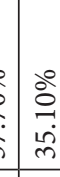 & 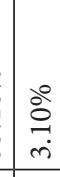 & $\underset{\stackrel{\partial}{\circ}}{\stackrel{\circ}{+}}$ & 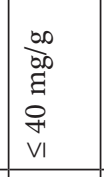 & & 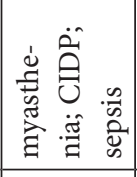 & 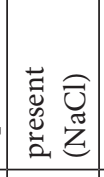 & 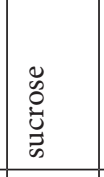 & 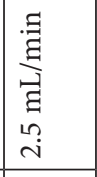 & 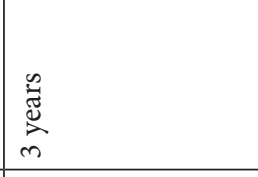 & 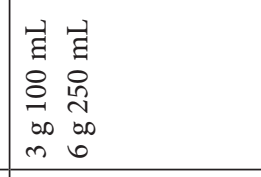 \\
\hline 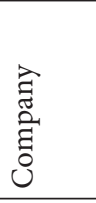 & $\begin{array}{l}\tilde{U} \\
\tilde{z} \\
0 \\
\vdots \\
.\end{array}$ & & & $1=$ & 品 & 今ે & 空 & 总 & 崩 & $\sum_{0.00}$ & 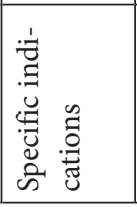 & 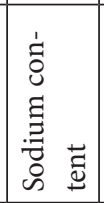 & 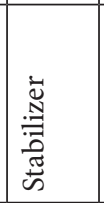 & 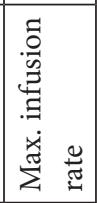 & 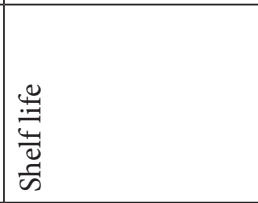 & 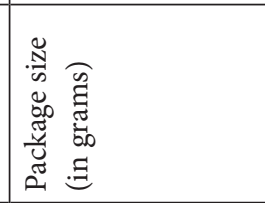 \\
\hline
\end{tabular}




\section{Conclusion}

Years of clinical practice allow us to conclude that intravenous immunoglobulin preparations are important in therapy of many diseases, including autoimmune blood disorders. High clinical efficacy on the one hand and relatively low incidence of adverse effects on the other make them particularly recommendable for patients in the youngest groups. It seems though that despite their qualities, IVIG are not sufficiently used in Poland. Statistics show that their use in our country is very low: only $12 \mathrm{~g}$ per 1000 inhabitants [46], while the average for Europe is $77 \mathrm{~g}$ per 1000 inhabitants and in the U.S. - as high as $144 \mathrm{~g}$ IgG per 1000 inhabitants! Additionally, according to National Health Found requirements, IVIGs should be used only in few indications described in each IVIG product characteristic (SPC). Worldwide use of IVIG is according to EBM (Evidence Based Medicine).

We hope that the short review of immunoglobulin preparations presented here will show doctors, especially paediatricians and pediatric haematologists, the benefits of using these drugs in the therapy of children with hematological diseases and will help them to choose a suitable preparation.

\section{References}

[1] Cherin P, Cabane J: Relevant Criteria for Selecting an Intravenous Immunoglobulin Preparation for Clinical Use. Biodrugs 2010, 24, 211-223.

[2] Wick M, Wick M, Heberger S, Simon H, Fateh-Moghadam A: Quality control of IgG preparations by protein analysis. Infusionsther Transfusionsmed 1996, 23 (suppl. 4), 55-59.

[3] Siegel J: Intravenous immune globulins: therapeutic, pharmaceutical, \& cost considerations. Pharm Practice News 1994, 21, 12-14.

[4] Cohn EJ, Strong LE, Hughes Jr WL, Mulford DJ, Ashworth JN, Melin M, Taylor HL: Preparation and properties of serum and plasma proteins. IV. A system for the separation into fractions of the protein and lipoprotein components of biological tissues and fluids. Journal of the American Chemical Society 68, 459-475, 1946.

[5] WHO Technical Report Series, No, 840, 1994. Annex 2. Requirements for the collection, processing and quality control of blood, blood components and plasma derivatives (Requirements for Biological Substances, No, 27, revised 1992)

[6] Gelfland EW: Critical decisions in selecting an intravenous immunoglobulin product. J Infus Nurs 2005, 28, 366-374.

[7] Hartung HP: Advances in the undentanding of the mechanism of action ofIVIg. J Neurol 2008, 255 Suppl, 3, 3-6.

[8] Looney RJ, Huggins J: Use of intravenous immunoglobulin G (IVIG). Best Pract Res Clin Haematol 2006, 19, $3-25$.

[9] Laguna P, Trzaska M: Charakterystyka i podział rekombinowanych preparatów krzepnięcia zarejestrowanych w Polsce w leczeniu hemofilii A i B z uwzględnieniem nowej klasy czynnika uzyskiwanego z komórek ludzkich. Nowa Pediatria 4/2010, 125-128.

[10] Hooper JA: Intravenous immunoglobulins evolution of commerciaI IVIG preparations. Immunol Allergy Clin North Am 2008, 28, 765-767.

[11] Ballow M: Safety of IGIV therapy and infusion-related adverse events. Immunol Res 2007, 38 (1-3), $122-132$.

[12] Lachert E, Antoniewicz-Papis J: Metody inaktywacji czynników chorobotwórczych w składnikach krwi. Journal of Transfusion Medicine 2010, tom 3, 3, 112-119.

[13] Svae TE, Frenzel W, Heger A, Römisch J: Dosing of solvent/detergent plasma versus single-donor fresh-frozen plasma. J Trauma 2007, Apr, 62, 1068-1069.

[14] Membrany. Teoria i praktyka. Redakcja: Romuald Wódzki. Fundacja rozwoju wydziału chemii. Uniwersytet Mikołaja Kopernika. Toruń 2003

[15] Yunoki M, Tanaka H, Urayama T, Hattori S: Prion removal by nanofiltration under different experimental conditions. Biologicals 2008, 36, 27-36.

[16] http://www.ema.europa.eu/ema/index.jsp?curl=pages/regulation/general/general_content_000069.jsp

[17] http://www.ema.europa.eu/ema/index.jsp?curl=pages/regulation/general/general_content_000071. jsp\&mid=WC0b01ac05800265d0

[18] Guideline on requirements for PMF certification CPMP/BWP/4663/03. http://ec.europa.eu/health/files/eudralex/ vol-2/c/466303en_08_2004_en.pdf

[19] Lin RY, Rodriguez-Baez G, Bhargave GA, Lin H: Intravenous gammaglobulin-associated renal impairment reported to the FDA: 2004-2009. Clinical Nephrology, Vol. 76, No. 5/2011 (365-372).

[20] Wojtecka A, Kade G, Bilbin-Bukowska A, Niemczyk S: Ostre uszkodzenie nerek wymagające terapii nerkozastępczej u chorego leczonego immunoglobulinami. Pol Merk Lek 2012, XXXII, 189, 173.

[21] Siwińska-Gołębiowska H, Borysewicz G, Buława E, Hofman H, Lambert I, Kunicka A, Jankowska B, Smogorzewska E: Immunochemical properties and therapeutic usefulness of the preparation Igalina produced by Biomed Probl Med Wieku Rozwoj 1979, 8, 152-164.

[22] Gelfand EW: Selecting Appropriate IGIV Therapy. CME/CE Released: 12/16/2003. http://www.medscape.org/ viewarticle/461288

[23] Eijkhout HW, van den Broek PJ, van der Meer JW: Substitution therapy in immunodeficient patient with antiIgA antibodies or severe adverse reactions to previous immunoglobulin therapy. Neth J Med 2003, 61, 213-217. 
[24] Czyżewska-Buczyńska A, Lewandowicz-Uszyńska A, Jankowski A: IgA istotny element układu odporności - wybrane zagadnienia. Postepy Hig Med Dosw 2007, 61, 38-47.

[25] Misbah S: Intravenous immunoglobulin in the Guillain-Barre syndrome. Products with low IgA content may be used in patients with total IgA deficiency. BMJ 1996, 313, 1400.

[26] Czyżewska-Buczyńska A, Lewandowicz-Uszyńska A, Jankowski A: IgA istotny element układu odporności - wybrane zagadnienia. Postepy Hig Med Dosw 2007, 61, 38-47.

[27] Giancarlo Liumbruno, Francesco Bennardello, Angela Lattanzio, Pierluigi Piccoli, Gina Rossetti as Italian Society of Transfusion Medicine and Immunohaematology (SIMTI) Working Party. Recommendations for the use of albumin and immunoglobulins. Blood Transfus 2009, 7, 216-234. Doi: 10.2450/2009.0094-09

[28] Ephrem A, Misra N, Hasan G: Immunomodulation of autoimmune and inflammatory disease with intravenous immunoglobulin. Clin Exp Med 2005, 5, 135-140.

[29] Dalakas MC: The use of intravenous immunoglobulin in the treatment of autoimmune neuromuscular disease: evidence-based indications and safety profile. Pharmacol Ther 2004, 102, 177-193.

[30] Knezevic-Maramica I, Kruskall MS: Intravenous immune globulins: an update for clinicians. Transfusion 2003, 43, 1460-1480.

[31] Prasad NK, Papoff G, Zeuner A: Therapeutic preparations of normal polyspecific IgG (IVIg) induce apoptosis in human lymphocytes and monocytes: a novel mechanism of action of IVIg involving the Fas apoptotic pathway. J Immunol 1998, 161, 3781-3790.

[32] Bayry J, Lacroix-Desmazes S, Carbonneil C: Inhibition of maturation and function of dendritic cells by intravenous immunoglobulin. Blood 2003, 101, 758-765.

[33] Ott VL, Fong DC, Cambier JC: FC gamma RIIB as a potential molecular target for intravenous gamma globulin therapy. J Allergy Clin Immunol 2001, 108 (Suppl 4), S95-98.

[34] Takei S, Arora YK, Walker AM: Intravenous immunoglobulin contains specific antibodies inhibitory to activation of T cells by staphylococcal toxin superantigens. J Clin Invest 1993, 91, 602-607.

[35] Kuhne T, Buchanan GR, Zimmerman S: A prospective comparative study of 2540 infants and children with newly diagnosed idiopathic thrombocytopenic purpura (ITP) from the Intercontinental Childhood ITP Study Group. J Pediatr 2003, 143, 605-608.

[36] Newland AC, Treleaven JG, Minchinton RM, Waters AH: High-dose intravenous IgG in adults with autoimmune thrombocytopenia. Lancet 1983, 1 (8316), 84-87.

[37] Neunert CE, Buchanan GR, Imbach P: Severe hemorrhage in children with newly diagnosed immune thrombocytopenic purpura. Blood 2008, 112, 4003-4008.

[38] Butros LJ, Bussel JB: Intracranial hemorrhage in immune thrombocytopenic purpura: a retrospective analysis. J Pediatr Hematol Oncol 2003, 25, 660-664.

[39] Lilleyman JS: Intracranial haemorrhage in idiopathic thrombocytopenic purpura: Paediatric Haematology Forum of the British Society for Haematology. Arch Dis Child 1994, 71, 251-253.

[40] Yang R, Han ZC: Pathogenesis and management of chronic idiopathic thrombocytopenic purpura: an update. Int J Hematol 2000, 71, 18-24.

[41] Krystyna Zawilska: Polskie zalecenia postępowania w pierwotnej małopłytkowości immunologicznej, opracowane przez Grupę ds. Hemostazy Polskiego Towarzystwa Transfuzjologów i Hematologów. Pol Arch Med Wewn 2010, 120 (Suppl), 2-28

[42] Schiavotto C, Ruggeri M, Rodeghiero F: Adverse reactions after high-dose intravenous immunoglobulin: incidence in 83 patients treated for idiopathic thrombocytopenic purpura (ITP) and review of the literature. Haematologica 1993, 78 (6 Suppl 2), 35-40.

[43] Packman C: Hemolytic anemia due to warm autoantibodies. Blood Rev 2008, 22, 17-31.

[44] Miloh T, Arnon R, Roman E, Hurlet A, Kerkar N, Wistinghausen B: Autoimmune hemolytic anemia and idiopathic thrombocytopenic purpura in pediatric solid organ transplant recipients, report of five cases and review of the literature. Pediatr Transplant 2011, 15, 870-878.

[45] Robinson P, Anderson D, Brouwers M: IVIG Hematology and Neurology Expert Panels. Evidencebased guidelines on the use of intravenous immunoglobulin for hematologic and neurologic conditions. Transfus Med Rev 2007, 21 (Suppl 1), S3-8.

[46] Anderson D, Ali K, Blanchette V: Guidelines on the use of intravenous immune globulin for hematologic conditions. Transfus Med Rev 2007, 21 (Suppl 1), S9-56.

[47] Immunoglobulins Market to 2017 - Off-Label Usage and Treatment of Primary Immunodeficiency Diseases and Neurological Disorders Stimulate Market Growth Published: September 2011. http://www.gbiresearch.com/ Report.aspx?ID=Immunoglobulins-Market-to-2016-Growth-to-be-Driven-by-Hyperimmunes-and-SpecialtyImmune-Globulin-Therapies\&ReportType=Industry_Report

\section{Address for correspondence:}

Paweł Łaguna

Department of Pediatrics Hematology and Oncology

Medical University of Warsaw

Marszałkowska 24

00-576 Warszawa

Poland

skazy@litewska.edu.pl

Conflict of interest: None declared

Received: 7.03.2014

Revised: 3.07.2014

Accepted: 25.08.2014 